\title{
YWHAQ wt Allele
}

National Cancer Institute

\section{Source}

National Cancer Institute. YWHAQ wt Allele. NCI Thesaurus. Code C52451.

Human YWHAQ wild-type allele is located in the vicinity of 2p25.1 and is approximately 47 $\mathrm{kb}$ in length. This allele, which encodes 14-3-3 protein theta, may be involved in the regulation of both cellular proliferation and apoptosis. The allele is expressed at elevated levels in amyotrophic lateral sclerosis patients. 